E-JURNAL EKONOMI DAN BISNIS UNIVERSITAS UDAYANA
Available online at https://ojs.unud.ac.id/index.php/EEB/index
Vol. 10 No. 09, September 2021, pages: $809-816$
e-ISSN: 2337-3067

\title{
PENGARUH PROFITABILITAS TERHADAP MANAJEMEN LABA PADA PERUSAHAAN KEUANGAN DAN MANUFAKTUR
}

\section{Putu Diah Kumalasari ${ }^{1}$}

\begin{tabular}{l} 
Article history: \\
\hline Submitted: 5 Mei 2021 \\
Revised: 10 Mei 2021 \\
Accepted: 9 Juli 2021 \\
\hline
\end{tabular}

\section{Keywords:}

Profitability;

Earnings Management;

$R O A$;

Discretionary Accruals;

\section{Kata Kunci:}

Profitabilitas;

Manajemen Laba;

ROA;

Discretionary Accruals;

\section{Koresponding:}

Universitas Mahasaraswati Denpasar, Bali, Iindonesia Email:

diahkumalasari@unmas.ac.id

\section{Abstract}

One of the elements of concern in financial statement is information related to profit. The achievement of targeted profit is one of the indicators that is used to measure the success of the company in carrying out its business activities. This encourages management to intervene on the value of reported earnings. This study aims to determine the effect of profitability on earnings management. The samples in this study were 32 financial companies and 74 manufacturing companies those were listed on the Indonesia Stock Exchange in 2019, which were obatained by purposive sampling method. The analysis technique used was the multiple linear regression. The results showed that profitability had a positive effect on earnings management in financial companies, while in manufacturing companies, it was found that there was no effect of profitability on earnings management.

\begin{tabular}{l} 
Abstrak \\
Salah satu elemen yang menjadi perhatian dalam laporan keuangan \\
\hline adalah informasi terkait laba. Pencapaian target laba merupakan salah satu \\
indikator yang digunakan untuk mengukur keberhasilan perusahaan dalam \\
menjalankan aktivitas bisnisnya. Hal tersebut mendorong manajemen untuk \\
melakukan intervensi terhadap nilai laba yang dilaporkan. Penelitian ini \\
bertujuan untuk mengetahui pengaruh profitabilitas terhadap manajemen \\
laba. Sampel dalam penelitian ini adalah 32 perusahaan keuangan dan 74 \\
perusahaan manufaktur yang terdaftar di Bursa Efek Indonesia tahun 2019, \\
yang ditentukan dengan metode purposive sampling. Teknik analisis yang \\
digunakan adalah regresi linier berganda. Hasil penelitian menunjukkan \\
bahwa profitabilitas berpengaruh positif terhadap manajemen laba pada \\
perusahaan keuangan, sedangkan pada perusahaan manufaktur, ditemukan \\
bahwa tidak terdapat pengaruh profitabilitas terhadap manajemen laba.
\end{tabular}

Universitas Mahasaraswati Denpasar, Bali, Indonesia

Email: diahkumalasari@unmas.ac.id 


\section{PENDAHULUAN}

Laporan keuangan menjadi perhatian utama bagi penggunanya untuk mengambil keputusan. Salah satu elemen yang menjadi perhatian dalam laporan keuangan adalah informasi terkait laba. Pencapaian target laba merupakan salah satu indikator yang digunakan untuk mengukur keberhasilan perusahaan dalam menjalankan aktivitas bisnisnya. Informasi laba juga digunakan sebagai dasar dalam pengambilan keputusan bisnis. Menyadari betapa pentingnya laba tersebut, maka manajemen berusaha untuk meningkatkan laba, sehingga dapat menguntungkan perusahaan, pihak eksternal maupun dirinya sendiri. Namun, terkadang fokus para pengguna laporan keuangan terhadap informasi laba mengabaikan proses terciptanya laba itu sendiri. Kondisi tersebut mendorong manajemen untuk melakukan praktik manajemen laba (Pramesti \& Budiasih, 2017).

Manajemen laba adalah suatu proses yang disengaja, menurut batasan standar akuntansi keuangan, yang bertujuan untuk mengarahkan pelaporan laba pada tingkat tertentu (Kusumawati, 2019). Berdasarkan teori keagenan, pemberian kuasa dari investor (prinsipal) pada manajer (agen) membuat pihak manajemen leluasa untuk memilih kebijakan akuntansi yang mempengaruhi besarnya laba (Giovani, 2019). Dengan memilih kebijakan akuntansi tertentu, manajemen sebagai pelaksana dan penanggungjawab operasional perusahaan dapat menaikkan dan menurunkan laba perusahaan sesuai keinginannya (Setyawan \& Harnovinsah, 2016).

Menurut Pratiwi \& Diana (2018), profitabilitas, yang diproksikan dengan Return On Assets (ROA), diduga menjadi faktor yang mempengaruhi manajemen laba. Profitabilitas merupakan kemampuan suatu perusahaan dalam menghasilkan laba selama periode tertentu pada tingkat penjualan, aset dan modal saham tertentu. Semakin tinggi profitabilitas suatu perusahaan, maka kinerja perusahaan dalam menghasilkan laba juga tinggi. Ketika profitabilitas yang diperoleh perusahaan kecil pada periode tertentu, maka akan mendorong manajemen perusahaan untuk melakukan manajemen laba dengan cara menjadikan laba pada laporan keuangan periode berjalan lebih tinggi daripada laba sesungguhnya. Hal ini dilakukan untuk menjaga kepercayaan investor dan kreditur, serta untuk kepentingan manajemen dalam hal memperoleh bonus. Sementara itu, ketika perusahaan memiliki profitabilitas yang tinggi pada periode tertentu, maka manajemen perusahaan akan melakukan tindakan manajemen laba dengan cara menjadikan laba pada laporan keuangan periode berjalan lebih rendah daripada laba sesungguhnya. Hal ini dilakukan untuk menghindari beban pajak dari pemerintah.

Hasil penelitian Tala \& Karamoy (2017), Lestari \& Wulandari (2019), serta Yanto \& Wati (2020) menunjukkan bahwa profitabilitas berpengaruh positif terhadap manajemen laba. Sementara itu, penelitian yang dilakukan oleh Agustia \& Suryani (2018), Fandriani \& Tunjung (2019) serta Wowor, et al. (2021) menemukan hasil bahwa profitabilitas tidak berpengaruh terhadap manajemen laba. Dengan adanya inkonsistensi hasil penelitian terdahulu tersebut, maka peneliti termotivasi untuk meneliti kembali pengaruh profitabilitas, yang diproksikan dengan ROA, terhadap manajemen laba pada perusahaan keuangan dan manufaktur yang terdaftar di Bursa Efek Indonesia (BEI) tahun 2019. Pada Maret 2019, BEI memanggil direksi PT Tiga Pilar Sejahtera Food Tbk (AISA) terkait dengan keluarnya hasil investigasi laporan keuangan 2017 oleh Ernst \& Young Indonesia (EY), yang mana menunjukkan adanya temuan terhadap dugaan penggelembungan pos akuntansi senilai $\mathrm{Rp} 4$ triliun serta beberapa dugaan lain. Akibat temuan ini, Otoritas Jasa Keuangan (OJK) meminta perusahaan untuk menyajikan ulang laporan keuangan 2017. Pada laporan keuangan tahun buku 2017 yang disajikan Kembali, Tiga Pilar membukukan rugi bersih senilai Rp 5,23 triliun, yang mana jumlah ini

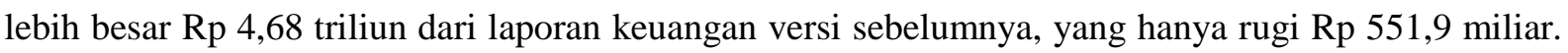
Hal ini membuktikan adanya praktik manajemen laba yang dilakukan oleh manajemen, yaitu dengan 
cara menurunkan rugi yang dilaporkan dari rugi yang sesungguhnya, sehingga rugi yang diperoleh perusahaan terlihat lebih kecil.

Perusahaan keuangan diduga berpotensi melakukan praktik manajemen laba, karena merupakan jenis usaha yang modal utamanya adalah kepercayaan nasabah. Selain itu, perusahaan keuangan cenderung memiliki risiko bisnis yang tinggi, misal kredit macet. Dengan tingkat laba yang tinggi, maka akan membuat masyarakat berasumsi bahwa perusahaan memiliki kinerja yang baik, sehingga mendapat kepercayaan dari nasabah. Begitu pula perusahaan manufaktur, yang juga diduga berpotensi melakukan praktik manajemen laba, karena merupakan emiten yang dominan di BEI, sehingga kinerjanya mendapatkan perhatian yang lebih dari pihak eksternal, baik itu investor, kreditur maupun pemerintah.

Berdasarkan pemaparan di atas, maka diduga bahwa profitabilitas berpengaruh positif terhadap manajemen laba pada perusahaan keuangan, maupun pada perusahaan manufaktur, yang terdaftar di BEI tahun 2019.

\section{METODE PENELITIAN}

Penelitian ini dilakukan pada perusahaan keuangan dan manufaktur yang terdaftar di BEI. Sampel dari penelitian ini merupakan perusahaan keuangan dan manufaktur yang menerbitkan laporan keuangan di BEI tahun 2019, masing-masing berjumlah 32 dan 74 perusahaan. Adapun jenis data yang digunakan dalam penelitian ini berupa data kuantitatif yang bersumber dari laporan keuangan perusahaan keuangan dan manufaktur yang terdaftar di BEI tahun 2019, dengan mengakses laman resmi BEI di www.idx.co.id.

Manajemen laba dalam penelitian ini diukur dengan tingkat discretionary accrual yang dihitung menggunakan modified jones model. Pertama, menentukan nilai total accrual (TAC) dengan rumus :

$$
\mathrm{TAC}_{\mathrm{it}}=\mathrm{NI}_{\mathrm{it}}-\mathrm{CFO}_{\mathrm{it}},
$$

dimana $\mathrm{NI}_{\mathrm{it}}$ adalah net income perusahaan i pada tahun $\mathrm{t}$ dan $\mathrm{CFO}_{\text {it }}$ adalah aliran kas dari aktivitas operasi perusahaan i tahun t. Kemudian, nilai TAC diestimasi dengan persamaan regresi Ordinary Least Square (OLS) atau kuadrat terkecil sederhana, yaitu :

$$
\frac{\text { TACit }}{\text { Ait-1 }}=\beta 1\left(\frac{1}{\text { Ait-1 }}\right)+\beta 2\left(\frac{\Delta \text { REVit }}{\text { Ait-1 }}\right)+\beta 3\left(\frac{\text { PPEit }}{\text { Ait-1 }}\right),
$$

dimana $\mathrm{TAC}_{\mathrm{it}}$ adalah total accruals perusahaan i pada tahun $\mathrm{t}, \mathrm{DAC}_{\mathrm{it}}$ adalah discretionary accruals perusahaan i pada tahun $\mathrm{t}, \mathrm{A}_{\mathrm{it}-1}$ adalah total aset perusahaan i pada $\mathrm{t}-1, \Delta \mathrm{REV}_{\mathrm{it}}$ adalah perubahan pendapatan perusahaan i pada tahun $\mathrm{t}$, dan $\mathrm{PPE}_{\mathrm{it}}$ adalah nilai aset tetap perusahaan I pada periode $\mathrm{t}$. Selanjutnya, koefisien regresi tersebut digunakan untuk menghitung NDAC (non discretionary accruals) dengan rumus :

$$
\mathrm{NDAC}_{\mathrm{it}}=\beta 1\left(\frac{1}{\text { Ait-1 }}\right)+\beta 2\left(\frac{\Delta \text { REVit }-\triangle \mathrm{RECit}}{\text { Ait }-1}\right)+\beta 3\left(\frac{\text { PPEit }}{\text { Ait-1 }}\right) .
$$

Kemudian, dengan menggunakan koefisien regresi tersebut, nilai discretionary current accruals (DAC) dihitung dengan rumus:

$$
\mathrm{DAC}_{\mathrm{it}}=\left(\frac{\mathrm{TAC}}{\text { Ait }-1}\right)-\mathrm{NDAC}_{\mathrm{it}}
$$

dimana $\triangle \mathrm{REC}_{\mathrm{it}}$ adalah perubahan piutang perusahaan $\mathrm{i}$ pada tahun $\mathrm{t}$ dan $\mathrm{NDAC}_{\mathrm{it}}$ adalah non discretionary accruals perusahaan i pada periode t. Sementara itu, profitabilitas dalam penelitian ini diukur dengan rumus :

$$
\mathrm{ROA}=\frac{\text { Laba bersih setelah pajak }}{\text { Total aset }} \times 100 .
$$

Penelitian ini menggunakan teknik analisis regresi linier sederhana, dengan dua model sebagai berikut: 
DAkeu $=b_{0}+b_{1}$ ROAkeu+e
DAman $=b_{0}+b_{1}$ ROAman + e

Keterangan:

$\begin{array}{ll}\text { DAkeu } & \text { : Manajemen laba perusahaan keuangan } \\ \text { DAman } & \text { : Manajemen laba perusahaan manufaktur } \\ \mathrm{b}_{0} & \text { : Konstanta } \\ \mathrm{b}_{1} & \text { : Koefisien regresi } \\ \text { ROAkeu } & \text { : Profitabilitas perusahaan keuangan } \\ \text { ROAman } & \text { : Profitabilitas perusahaan manufaktur } \\ \mathrm{e} & \text { : Variabel pengganggu }\end{array}$

Model pertama menguji hubungan antara ROA perusahaan keuangan dan manajemen laba. Model kedua menguji hubungan antara ROA perusahaan manufaktur dan manajemen laba.

\section{HASIL DAN PEMBAHASAN}

Berdasarkan hasil uji statistik deskriptif yang disajikan pada Tabel 1, ditemukan bahwa nilai minimum dan maksimum manajemen laba perusahaan keuangan masing-masing adalah sebesar 0,495 dan 0,271. Sementara itu, nilai minimum dan maksimum manajemen laba perusahaan manufaktur masing-masing adalah sebesar -0,388 dan 0,090. Angka discretionary accrual yang bernilai negatif menunjukkan bahwa perusahaan melakukan manajemen laba dengan cara menurunkan laba, sedangkan nilai positif menunjukkan bahwa perusahaan melakukan manajemen laba dengan cara menaikkan laba. Angka-angka tersebut menunjukkan bahwa baik itu perusahaan keuangan maupun manufaktur tersebut melakukan manajemen laba dengan motif yang berbeda-beda. Selain itu, hasil uji juga menunjukkan nilai rata-rata manajemen laba sebesar -0,027 untuk perusahaan keuangan, dan 0,083 untuk perusahaan manufaktur. Artinya, rata-rata perusahaan keuangan tersebut terindikasi melakukan manajemen laba dengan cara menaikkan laba yang lebih tinggi dibandingkan dengan perusahaan manufaktur.

Tabel. 1

Hasil Uji Statistik Deskriptif

\begin{tabular}{lcccc}
\hline & $\mathrm{N}$ & Minimum & Maksimum & Rata-rata \\
\hline Profitabilitas perusahaan keuangan & 32 & $-0,271$ & 0,125 & 0,014 \\
Profitabilitas perusahaan manufaktur & 74 & $-0,173$ & 0,590 & 0,068 \\
Manajemen laba perusahaan keuangan & 32 & $-0,495$ & 0,271 & $-0,027$ \\
Manajemen laba perusahaan manufaktur & 74 & $-0,388$ & 0,090 & $-0,083$ \\
\hline
\end{tabular}

Sumber: Data diolah, 2021

Nilai profitabilitas minimum, maksimum, dan rata-rata perusahaan keuangan masingmasing sebesar $-0,271,0,125$ dan 0,014. Sementara itu, nilai profitabilitas minimum, maksimum, dan rata-rata perusahaan manufaktur masing-masing sebesar $-0,173,0,590$ dan 0,068 . Nilai profitabilitas (diukur dengan ROA) yang lebih tinggi menunjukkan bahwa perusahaan lebih efektif dalam mengelola asetnya dan lebih produktif dalam menghasilkan laba bersih yang lebih besar. Hal ini mengindikasikan bahwa rata-rata perusahaan manufaktur yang menjadi sampel dalam penelitian ini memiliki kinerja yang lebih baik daripada perusahaan keuangan.

Sebelum dilakukan analisis regresi linier sederhana, terlebih dahulu dilakukan uji asumsi klasik, yaitu uji normalitas, pada kedua model persamaan yang diajukan dalam penelitian ini. Uji normalitas dalam penelitian ini menggunakan normal probability plot, yang hasilnya disajikan pada Gambar 1 dan Gambar 2. Gambar menunjukkan bahwa titik-titik menyebar mendekati garis diagonal, 
maka data tersebut dapat dianggap berdistribusi normal, sehingga selanjutnya dapat dilakukan analisis regresi linier sederhana.

Normal P-P Plot of Regression Standardized Residual

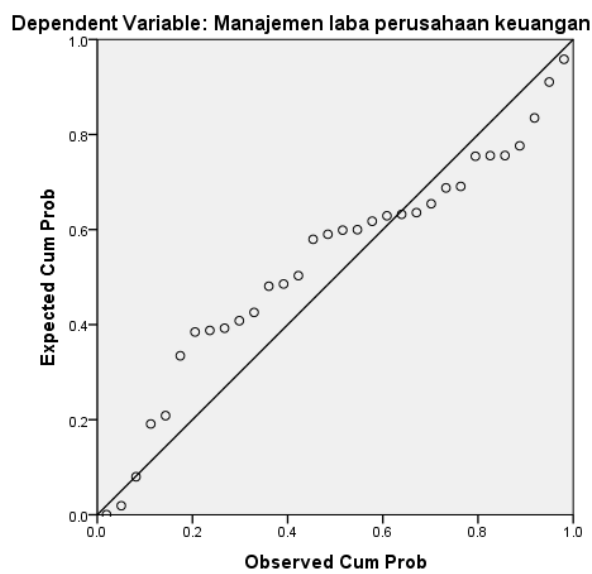

Sumber: Data diolah, 2021

Gambar 1.

Hasil Uji Normalitas Data Perusahaan Keuangan

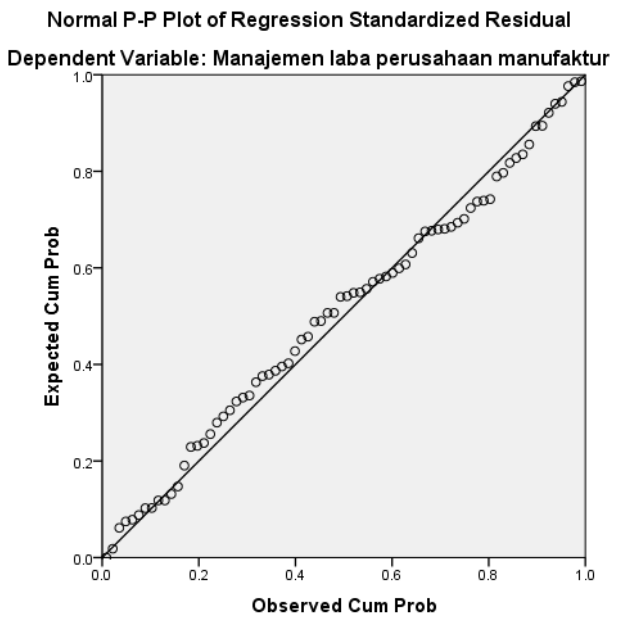

Sumber: Data diolah, 2021

Gambar 2.

Hasil Uji Normalitas Data Perusahaan Manufaktur

Hipotesis pertama dalam penelitian ini menguji pengaruh profitabilitas terhadap manajemen laba pada perusahaan keuangan yang terdaftar di BEI tahun 2019. Hasil uji hipotesis pertama disajikan pada Tabel 2:

Tabel. 2

Hasil Uji Hipotesis Pertama

\begin{tabular}{ccccc}
\hline & $\mathrm{b}$ & Std. Error & $\mathrm{t}$ & Sig. \\
\hline Konstan & $-0,044$ & 0,023 & $-1,921$ & 0,064 \\
ROAkeu & 1,201 & 0,340 & 3,535 & 0,001 \\
$\mathrm{R}=0,542$ & & & & \\
$\mathrm{R}^{2}=0,294$ & & & & \\
\hline Sumber: & & &
\end{tabular}

Sumber: Data diolah, 2021 
Tabel. 2 menunjukkan bahwa nilai $\mathrm{R}$ adalah 0,542 , yang berarti terdapat hubungan yang lemah antara profitabilitas dan manajemen laba pada perusahaan keuangan. Nilai $R^{2}$ sebesar 0,294 menunjukkan bahwa varian dari profitabilitas mampu menjelaskan varian manajemen laba pada perusahaan keuangan sebesar $29,4 \%$, sedangkan sisanya $70,6 \%$ dijelaskan oleh variabel lain yang tidak dimasukkan ke dalam model. Variabel profitabilitas memiliki $t_{\text {hitung }}$ sebesar 3,535 dengan tingkat signifikansi $0,001<0,05$, sehingga hipotesis pertama dalam penelitian ini diterima, yaitu profitabilitas berpengaruh positif terhadap manajemen laba pada perusahaan keuangan yang terdaftar di BEI tahun 2019. Artinya, kenaikan nilai profitabilitas, yang diukur dengan ROA, akan diikuti dengan kenaikan nilai manajemen laba, yang diukur dengan tingkat discretionary accrual, pada perusahaan keuangan.

Perusahaan keuangan merupakan jenis usaha yang modal utamanya adalah kepercayaan nasabah. Selain itu, perusahaan keuangan cenderung memiliki risiko bisnis yang tinggi, misalnya kredit macet pada bank. Apabila terjadi kredit macet, maka pendapatan bunga bank juga akan menurun. Hal ini tentu akan berpengaruh terhadap penilaian kinerja perusahaan. Kondisi seperti ini membuat manajemen melakukan intervensi terhadap nilai laba yang dilaporkan, agar kinerja perusahaan terlihat baik. Semakin tinggi profitabilitas suatu perusahaan, maka kinerja perusahaan dalam menghasilkan laba juga tinggi. Dengan tingkat laba yang tinggi, maka akan membuat masyarakat berasumsi bahwa perusahaan memiliki kinerja yang baik, sehingga mendapat kepercayaan dari nasabah. Hasil penelitian ini sejalan dengan hasil penelitian Kamil \& Ariyani (2017), Basir \& Muslih (2019) serta Ardli \& Yuliandhari (2019), yang menunjukkan bahwa profitabilitas berpengaruh positif terhadap manajemen laba.

Hipotesis kedua dalam penelitian ini menguji pengaruh profitabilitas terhadap manajemen laba pada perusahaan manufaktur yang terdaftar di BEI tahun 2019. Hasil uji hipotesis pertama disajikan pada Tabel 3:

Tabel. 3

Hasil Uji Hipotesis Kedua

\begin{tabular}{lcccc}
\hline & $\mathrm{b}$ & Std. Error & $\mathrm{t}$ & Sig. \\
\hline \multicolumn{1}{c}{ Konstan } & $-0,090$ & 0,011 & $-8,177$ & 0,064 \\
ROAman & 0,107 & 0,085 & 1,263 & 0,211 \\
$\mathrm{R}=0,147$ & & & \\
$\mathrm{R}^{2}=0,022$ & & & & \\
\hline Sumber: Data diolah, 2021 & & &
\end{tabular}

Tabel. 3 menunjukkan bahwa variabel profitabilitas memiliki $t_{\text {hitung }}$ sebesar 1,263 dengan tingkat signifikansi $0,211>0,05$, sehingga hipotesis kedua dalam penelitian ini ditolak, dimana profitabilitas tidak berpengaruh terhadap manajemen laba pada perusahaan manufaktur yang terdaftar di BEI tahun 2019. Artinya, kenaikan nilai profitabilitas, yang diukur dengan ROA, tidak diikuti dengan kenaikan nilai manajemen laba, yang diukur dengan tingkat discretionary accrual, pada perusahaan manufaktur. Profitabilitas menunjukkan kemampuan suatu perusahaan dalam menghasilkan laba selama periode tertentu pada tingkat penjualan, aset dan modal saham tertentu. Dari hasil uji statistik deskriptif diketahui bahwa nilai rata-rata profitabilitas perusahaan manufaktur lebih tinggi daripada nilai rata-rata profitabilitas perusahaan keuangan. Apabila profitabilitas tinggi, maka kinerja perusahaan dikatakan baik dan sebaliknya, apabila profitabilitas rendah, maka kinerja perusahaan dikatakan buruk (Noviarty \& Donela, 2019). Semakin tinggi profitabilitas suatu perusahaan, maka kinerja perusahaan dalam menghasilkan laba juga tinggi. Tingginya laba yang dihasilkan cenderung membuat manajemen untuk tidak melakukan intervensi terhadap nilai laba yang dilaporkan, sehingga manajemen tidak merasa perlu untuk melakukan manajemen laba. Hasil penelitian ini sejalan dengan hasil penelitian Gunawan, et al. (2015) dan Astuti (2017), yang menunjukkan bahwa profitabilitas tidak berpengaruh terhadap manajemen laba. 


\section{SIMPULAN DAN SARAN}

Berdasarkan hasil pengujian yang dilakukan, dapat disimpulkan bahwa profitabilitas berpengaruh positif terhadap manajemen laba pada perusahaan keuangan yang terdaftar di BEI tahun 2019. Artinya, kenaikan nilai profitabilitas akan diikuti dengan kenaikan nilai manajemen laba pada perusahaan keuangan. Namun, hasil pengujian pada perusahaan manufaktur menunjukkan hasil yang berbeda, dimana profitabilitas tidak berpengaruh terhadap manajemen laba pada perusahaan manufaktur yang terdaftar di BEI tahun 2019. Artinya, kenaikan nilai profitabilitas tidak diikuti dengan kenaikan nilai manajemen laba pada perusahaan manufaktur. Praktik manajemen laba akan mengurangi kualitas dari laba yang dilaporkan, sehingga diharapkan investor tidak hanya berfokus pada informasi laba, melainkan juga patut mempertimbangkan informasi lainnya, seperti arus kas perusahaan, dalam membuat keputusan investasi.

Penelitian selanjutnya dapat mempertimbangkan untuk menggunakan rasio profitabilitas lainnya, seperti Net Profit Margin (NPM) ataupun Return On Equity (ROE). Selain itu, dari hasil pengujian diketahui bahwa profitabilitas tidak berpengaruh terhadap manajemen laba pada perusahaan manufaktur, untuk itu, bagi peneliti selanjutnya dapat mempertimbangkan untuk melibatkan variabel lain, seperti mekanisme Good Corporate Governance (GCG), independensi auditor maupun perencanaan pajak.

\section{REFERENSI}

Agustia, Y. P., \& Suryani, E. (2018). Pengaruh Ukuran Perusahaan, Umur Perusahaan, Leverage, Dan Profitabilitas Terhadap Manajemen Laba (Studi Pada Perusahaan Pertambangan yang Terdaftar di Bursa Efek Indonesia Periode 2014-2016). Jurnal ASET (Akuntansi Riset), 10(1), 71-82. https://doi.org/10.17509/jaset.v10i1.12571

Ardli, D. M., \& Yuliandhari, W. S. (2019). Pengaruh Pajak Tangguhan, Profitabilitas, Dan Leverage Terhadap Earnings Management (Studi Pada Perusahaan Perbankan Yang Terdaftar Pada Bei 2010-2017). Jurnal Aksara Public, 3(9), 210-223. http://www.aksarapublic.com/index.php/home/article/view/200

Astuti, P. W. (2017). Pengaruh Profitabilitas, Ukuran Perusahaan, Leverage, Dan Kualitas Audit Terhadap Manajemen Laba (Studi Empiris pada Perusahaan Manufaktur yang Terdaftar di Bursa Efek Indonesia Periode 2012-2015). Skripsi, 87(1,2), i-13.

Basir, S. I., \& Muslih, M. (2019). Pengaruh Free Cash Flow, Leverage, Profitabilitas Dan Sales Growth Terhadap Manajemen Laba. Jurnal AKSARA PUBLIC, 3(2), 104-111.

Fandriani, V., \& Tunjung, H. (2019). Pengaruh Surplus Arus Kas Bebas, Ukuran Perusahaan, Leverage Dan Kualitas Audit Terhadap Manajemen Laba. Diponegoro Journal of Accounting, 7(4), 505-514.

Giovani, M. (2019). Pengaruh Struktur Kepemilikan, Tata Kelola Perusahaan, Dan Karakteristik Perusahaan Terhadap Manajemen Laba. Jurnal Akuntansi Bisnis, 15(2), 290. https://doi.org/10.24167/jab.v16i1.1367

Gunawan, I. K., Darmawan, N. A. S., \& Purnamawati, I. G. A. (2015). Pengaruh Ukuran Perusahaan, Profitabilitas, dan Leverage Terhadap Manajemen Laba. Jurnal Akuntansi Program S1 Universitas Pendidikan Ganesha, 03(1). https://doi.org/http://dx.doi.org/10.23887/jimat.v3i1.5272

Kamil, I., \& Ariyani, M. (2017). Manajemen Laba Ditinjau Dari Faktor Beban Pajak Tangguhan , Profitabilitas dan Leverage. Jurnal Online Insan Akuntan, 2(2), 259-270.

Kusumawati, E. (2019). Determinan Manajemen Laba: Kajian Empiris Pada Perusahaan Manufaktur Go Publik Di Bursa Efek Indonesia. Riset Akuntansi Dan Keuangan Indonesia, 4(1), $25-42$. https://doi.org/10.23917/reaksi.v4i1.6935

Lestari, K. C., \& Wulandari, S. O. (2019). Pengaruh Profitabilitas terhadap Manajemen Laba (Studi Kasus Pada Bank Yang Terdaftar Di BEi Tahun 2016- 2018). Jurnal Akademi Akuntansi, 2(1), $20-35$. https://ejournal.umm.ac.id/index.php/jaa/article/view/7878

Noviarty, H., \& Donela, V. (2019). Pengaruh Kompensasi Eksekutif Terhadap Manajemen Laba Dengan Profitabilitas Sebagai Variabel Moderating (Studi Empiris Pada Perusahaan Perbankan Yang Terdaftar Di Bursa Efek Indonesia). JAAKFE UNTAN (Jurnal Audit Dan Akuntansi Fakultas Ekonomi Universitas Tanjungpura), 8(1), 43-72. https://doi.org/10.26418/jaakfe.v8i1.40436

Pramesti, I. A. J., \& Budiasih, I. G. A. N. (2017). Pengaruh Asimetri Informasi, Leverage, Kepemilikan 
Manajerial Dan Kepemilikan Institusional Pada Manajemen Laba. E-Jurnal Akuntansi, 21(6), 200-226.

Pratiwi, A. W., \& Diana, P. (2018). Pengaruh Profitabilitas, Kualitas Audit, Independensi Auditor, Ukuran Perusahaan, Dan Leverage Terhadap Manajemen Laba. Jurnal Bina Akuntansi, 5(2), 278-309. https://doi.org/10.52859/jba.v5i2.24

Setyawan, B., \& Harnovinsah. (2016). Pengaruh Beban Pajak Tangguhan, Profitabilitas, Dan Perencanaan Pajak Terhadap Manajemen Laba (Studi Empiris Pada Perusahaan Manufaktur Sub Sektor Otomotif Dan Komponen Yang Terdaftar Di Bursa Efek Indonesia Periode 2010-2014). Keberlanjutan: Jurnal Manajemen Dan Akuntansi, $1(1), \quad$ 15-40. https://doi.org/http://dx.doi.org/10.32493/keberlanjutan.v1i1.y2016.p15-40

Tala, O., \& Karamoy, H. (2017). Analisis Profitabilitas Dan Leverage Terhadap Manajemen Laba Pada Perusahaan Manufaktur Di Bursa Efek Indonesia. Accountability, 6(1), 57-64. https://doi.org/10.32400/ja.16027.6.1.2017.57-64

Wowor, J. C. J., Morasa, J., Rondonuwu, S., Morasa, J., Ekonomi, F., Akuntansi, J., Wowor, J. C. J., Morasa, J., \& Rondonuwu, S. (2021). Jurnal EMBA Vol . 9 No . 1 Januari 2021, Hal . 589-599. Jurnal Emba: Jurnal Riset Ekonomi, Manajemen, Bisnis Dan Akuntansi, 9(1), 589-599.

Yanto, D. O., \& Wati, L. N. (2020). Pengaruh Struktur Modal, Profitabilitas Terhadap Determinasi Manajemen Laba Dan Strategi Diversifikasi. Jurnal Akuntansi, 9(1), 47-57. https://doi.org/10.37932/ja.v9i1.100 